\title{
LC-MS Analysis of Phytocomponents in the Methanol Extract of Piper Sarmentosum Leaves
}

\author{
Cutt Fazzlieanie Bactiar, Nur Azlina Mohd Fahami*
}

\section{Cutt Fazzlieanie Bactiar, Nur Azlina Mohd Fahami*}

Department of Pharmacology, Faculty of Medicine, UKMMC, Universiti Kebangsaan Malaysia, Kuala Lumpur, MALAYSIA.

\section{Correspondence}

Dr. Nur Azlina Mohd Fahami

Department of Pharmacology, Faculty of Medicine Universiti Kebagsaan Malaysia, Jalan Yaacob Latif, 56000, Cheras, Kuala Lumpur, MALAYSIA.

Phone no: 603-91459574

Fax no: 603-91459547;

E-mail: nurazlinamf@ukm.edu.my

History

- Submission Date: 26-12-2018;

- Review completed: 30-04-2019;

- Accepted Date: 17-05-2019.

DOI : 10.5530/pj.2019.11.167

Article Available online http://www.phcogj.com/v11/i5

\section{Copyright}

(C) 2019 Phcogj.Com. This is an openaccess article distributed under the terms of the Creative Commons Attribution 4.0 International license.

\section{ABSTRACT}

Background: Piper sarmentosum is a cultivated plant that grows wildly in the tropical and subtropical region including in Malaysia. It has a wide usage in traditional medicine and have a variety of active chemical constituents. Aim: The aim of this study is to isolate and identify the active compounds from the methanol extracts of leaves of $P$. Sarmentosum. Methods and Materials: The fresh leaves of Piper sarmentosum were collected from the Ethnobotanic garden of Forest Research Institute Malaysia (FRIM) after being identified and confirmed by a plant taxonomist from Medicinal Plant Divison (Voucher specimen code no: FRI 45870). The methanolic extraction procedure were performed at FRIM labrotory. The extract was then sent to Research and Instrumentation Management Centre (CRIM) UKM for Liquid Chromatography Mass Spectrometry (LCMS) analysis. Results: Fifteen compounds were isolated from the fresh leaves of Piper sarmentosum. Six of these have been previously isolated from the roots and essential oil of this plant: (2) Naringenin, (3) Methyl piperate, (5) Beta-Asarone, (6) Brachyamide B, (8) Piperitol and (9)(10) Guineensine. (1)(12) Didymin, (4) Quercetin, (7) Amurensin (11) Hesperidin, and (15) Difucol are new for P. Sarmentosum (Piperaceae). Conclusions: From the result, it is evident that Piper sarmentosum contains various bioactive compounds. (1)(12) Didymin, (4) Quercetin, (7) Amurensin, (11) Hesperidin, and (15) Difucol are new natural compounds that have not been reported before.

Key words: Piper sarmentosum, Liquid-chromatography mass-spectrometry (LC-MS) analysis, Lignan, Naringine, Flavanoids.

\section{INTRODUCTION}

Piper sarmentosum is a cultivated plant that grows wildly in tropical and subtropical region like Malaysia, Thailand and Indonesia. Piper sarmentosum belongs to Piperaceae family, which locally known as "kaduk" in Malaysia, is a herbal plant that have a wide usage in traditional medicines $^{1-3}$ and also as food flavoring agents ${ }^{4}$ and pest control agents. ${ }^{5}$ It is a glabrous, creeping terrestrial herb about $20 \mathrm{~cm}$ tall with aromatic odor and pungent taste. ${ }^{2}$ The leaves are ovale in shape, about 5-10 cm wide and 7-15 cm long. Most of the parts of the plant have potential benefits.

Piper sarmentosum contains a variety of active chemical constituents such as alkaloid (amides), pyrones, flavanoid, sterols, phenylpropanoids and neolignans ${ }^{6,7}$ most of which have been found to be active against bacteria. ${ }^{1,8,9}$ Locally in Malaysia, Piper sarmentosum leaves and roots are applied to the forehead to comfort headache while its decoction is known to relieve muscle weakness and also pain. Furthermore, both roots and leaves of this plant are essential for the treatment of toothache, fungoid dermatitis on feet, coughing asthma and pleurisy. ${ }^{10}$ In Thailand, roots of Piper sarmentosum are used for stomach ache while the leaves had been shown to reduce gastritis. ${ }^{11}$

The methanolic extracts of Piper sarmentosum leaves was found to have a higher level of antioxidant activity compared to other traditional medicine plants. ${ }^{12}$ It's high antioxidant activity might be attributed to the chemical components presents in the plant such as vitamin $\mathrm{C}$ and $\mathrm{E}$, xanthopylls, carotenes and phenols. ${ }^{12}$ Moreover, the ethanolic extract of leaves has been reported to reduce blood sugar level in alloxan diabetic rabbits ${ }^{13}$ while methanolix extract of leaves was found to possess a marked neuromuscular blocking activity in rat phrenic nerve-hemidiaphragm preparation. $^{14}$ In addition, the chloroform and methanol extracts of leaves showed considerable antiplasmodial activity against Plasmodium falciparum and Plasmodium berghei parasites. ${ }^{15}$ In this present work, the phytochemical screening using LC-MS were perform to identify more phytoconstituents in the methanolic extract of Piper sarmentosum.

\section{MATERIALS AND METHOD}

\section{Plant materials}

The fresh leaves of Piper sarmentosum were collected from the Ethnobotanic garden of Forest Research Institute Malaysia (FRIM) after being identified and confirmed by a plant taxonomist from MedicinalPlant Divison (Voucher specimen code no: FRI 45870). The methanolic extraction procedure were performed at FRIM labrotory. The extract was then sent to Research and Instrumentation Management Centre (CRIM) UKM for Liquid Chromatography Mass Spectrometry (LCMS) analysis.

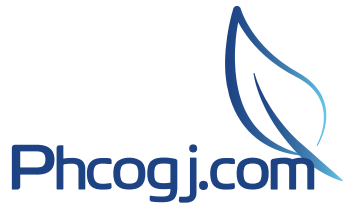

Cite this article: Bactiar CF, Nur Azlina MF. LC-MS Analysis of Phytocomponents in the Methanol Extract of Piper Sarmentosum Leaves. Pharmacog J. 2019;11(5):1071-6. 


\section{Preparation of methanolic extract of Piper sarmentosum}

Fresh leaves of the plants were cleaned with tap water and dried at room temperature before being chopped into small pieces. The extraction procedure followed Sawangjaroen et al. ${ }^{16}$ In brief, $250 \mathrm{~g}$ leaves were mixed with $2.5 \mathrm{~L}$ methanol. This mixture was heated using Soxhlet at $45-60^{\circ} \mathrm{C}$, after which the methanol undergoes evaporation. The paste material produced was kept at $4^{\circ} \mathrm{C}$ until use. The percentage of yield from the crude dried extract is $\approx 10 \%$.

\section{Phytochemical studies}

The methanolic extracts of leaves of $P$. sarmentosum were subjected to qualitative chemical tests to detect the presence of various classes of phytoconstituents. Liquid chromatography - Mass Spectrometry (LCMS) UHPLC system was equipped with an autosampler and the employed column was a Waters nanoAcquityHSS $\mathrm{T}_{3}, 1.8 \mu \mathrm{m} \times 100 \mathrm{~mm}$. The mobile phases were water $0.1 \%$ formic acid (A) and $90 \%$ acetonitrile in water $0.1 \%$ formic acid (B) at a flow rate of $500 \mu \mathrm{L} \mathrm{min}{ }^{-1}$. The LC conditions were $5 \% \mathrm{~B}$ during $0-3 \mathrm{~min}$, a linear increase from 5 to $20 \% \mathrm{~B}$ during $95 \%$ B during $55-63$ min followed by 15 min of maintenance. A Thermo Electron LTQ-Orbitrap XL mass spectrometer equipped with a nano electrospray ion source (ThermoFisher Scientific, Bremen, Germany) and operated under Xcalibur 2.1 version software, was used in positive ionization mode for the MS analysis using data-dependent automatic switching between MS and MS/MS acquisition modes. ${ }^{17}$

\section{Identification of phytocomponents}

Interpretation on mass-spectrum LC-MS was conducted using the database of MassBank Japan having more than 62,000 patterns. The spectrum of the unknown components was compared with the spectrum of known components stored in the MassBank library. The name, molecular weight, and structure of the components of the test materials were ascertained.

\section{RESULTS}

\section{Phytocomponents of methanol extract of Piper sarmentosum}

LC-MS chromatogram analysis of the methanolic extract of $P$. sarmentosum showed fifteen peaks which indicates the presence of fifteen phytochemical constituents (Figure 1). On comparison of the mass spectra of the constituents with the MassBank library, the fifteen phytocompounds were characterized and identified (Table 1). The molecular structures of various compound from piper sarmentosum is shown in Figure 2. While the various phytochemicals which contribute to the medicinal activities of the plant were shown in Table 2 .

With the standard reference graphs, the compounds are elucidated using molecular weight. The highest peak at the particular retention time is found out and the compounds with the highest peak are BetaAsarone; Brachyamide B; Amurensin; Guineensine; Hesperidin; Didymin; Rutin and Difucol.

\section{DISCUSSION}

From this study, fifteen compounds were isolated from methanol extracts of Piper sarmentosum leaves and identified by spectroscopic methods; Didymin (1)(12) $)^{18}$ Naringenin (2) ${ }^{19,20}$, Methyl piperate (3) $)^{21,22}$, Quercetin (4) ${ }^{23}$, Beta Asarone (5) ${ }^{24}$, Brachyamide B (6) ${ }^{22}$, Amurensin (7), Piperitol (8), Guineensine (9)(10) ${ }^{25,26}$, Hesperidin (11), Rutin (13) ${ }^{19,27}$, Malvidin (14), Difucol (15). The structures of compounds 1-15 are presented in Figure 1.

Previous phytochemical studies on this plant; including its leaves, root and fruits had resulted in the isolation of a number of amides and phenylpropanoids. ${ }^{22,28,8}$ This is the first report of the isolation of compounds 1, 4, 7, 11, 12 and 15 from Piper sarmentosum. Didymin (1)(12), a dietary flavonoid glycoside which normally can be found from citrus fruits, possesses antioxidant properties. ${ }^{29}$ It is an anticancer agent. Vimala et al. ${ }^{20}$ showed Piper sarmentosum contains a very

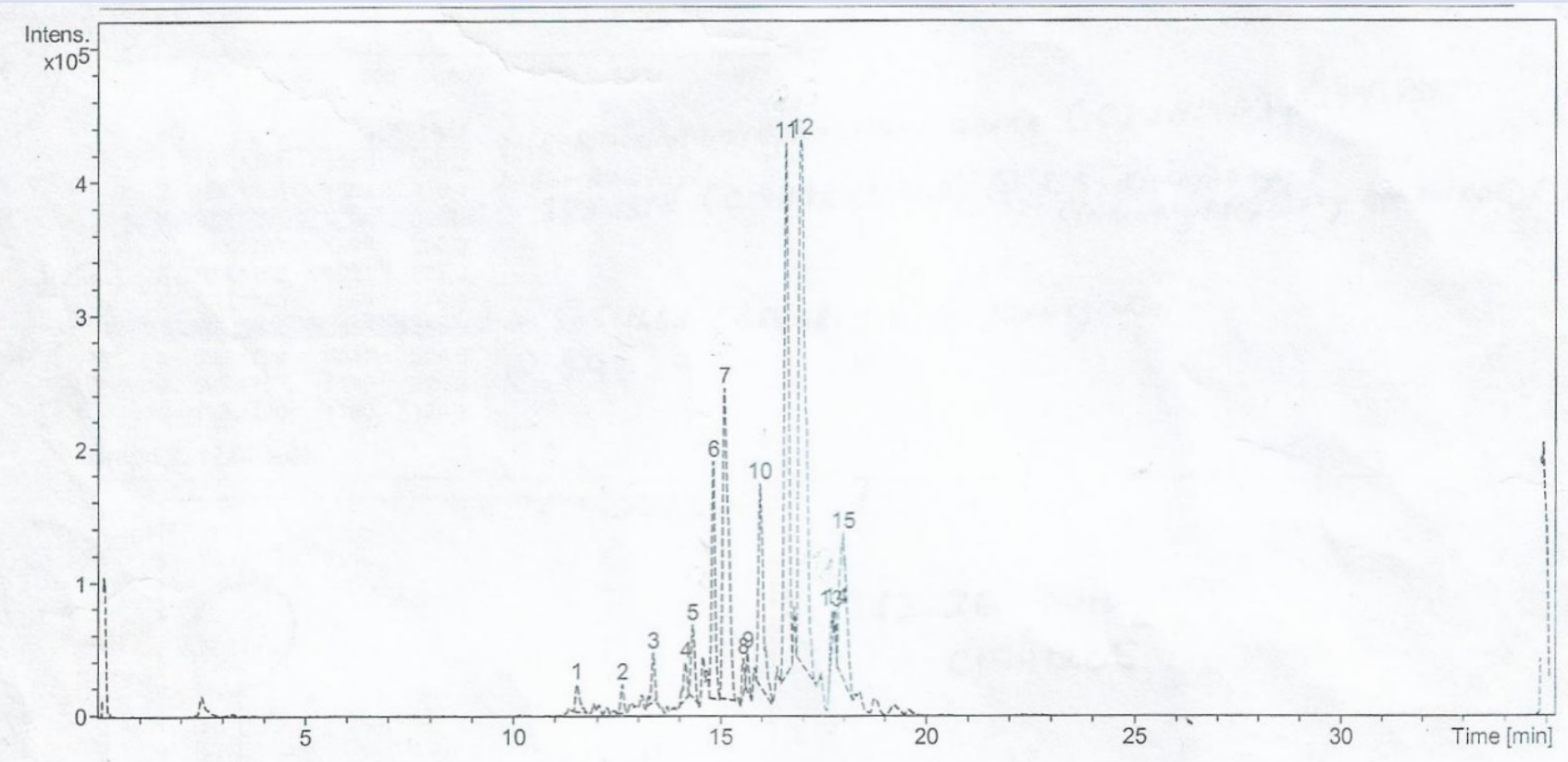

Figure 1: LC-MS chromatogram of Piper sarmentosum methanolic extracts. 


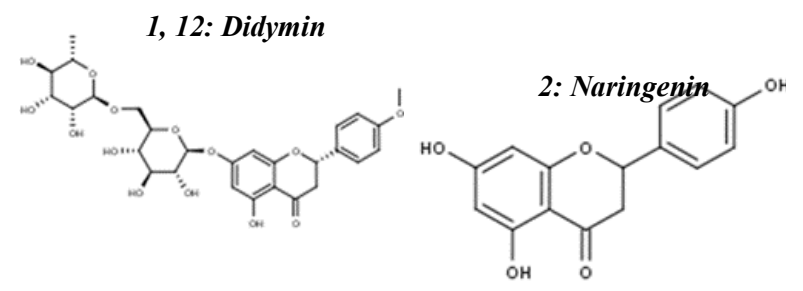<smiles>COC(=O)/C=C/C=C/c1ccc2c(c1)OCO2</smiles>

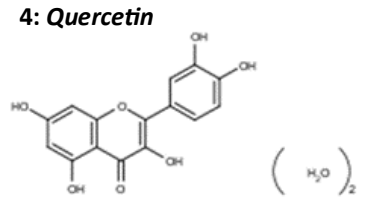<smiles>C/C=C\c1cc(OC)c(OC)cc1OC</smiles><smiles>O=C(/C=C/CCCC/C=C/c1ccc2c(c1)OCO2)N1CCCC1</smiles>

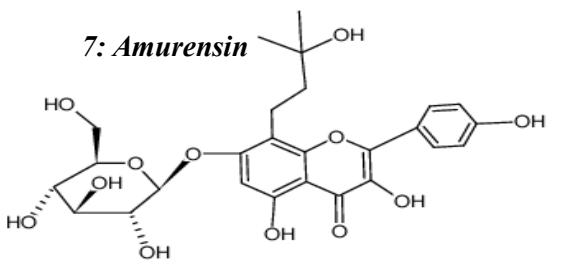

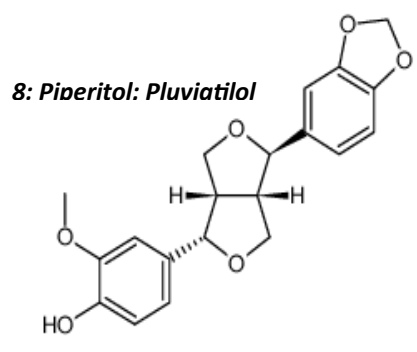<smiles>CC(C)CCC/C=C/CCCCNC(=O)/C=C/C=C\c1ccc2c(c1)OCO2</smiles><smiles>COc1ccc([C@H]2CC(=O)c3c(O)cc(O[C@@H]4O[C@H](CO[C@H]5O[C@@H](C)[C@@H](O)[C@H](O)[C@H]5O)[C@@H](O)[C@H](O)[C@H]4O)cc3O2)cc1O</smiles>

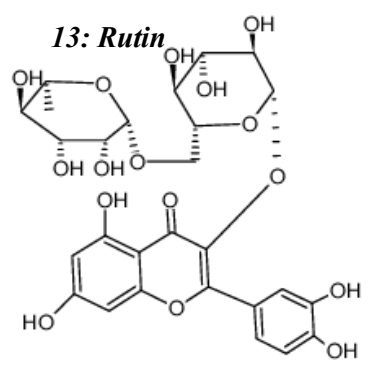<smiles>COc1cc(-c2[o+]c3cc(O)cc(O)c3cc2O)cc(OC)c1O</smiles><smiles>Oc1cc(O)c(-c2c(O)cc(O)cc2O)c(O)c1</smiles>

Figure 2: The molecular structures of isolated compounds from Piper sarmentosum.

Table 1: Composition of phytocomponents in the methanol extract of fresh leaves of $P$. sarmentosum.

\begin{tabular}{ccccc}
\hline Peak & Retention time & Name of compound & Formula & Molecular weight \\
\hline 1 & 11.53 & Didymin & $\mathrm{C}_{28} \mathrm{H}_{34} \mathrm{O}_{14}$ & 594.56 \\
2 & 12.62 & Naringenin & $\mathrm{C}_{15} \mathrm{H}_{12} \mathrm{~N}_{5}$ & 272.25 \\
3 & 13.38 & Methyl piperate & $\mathrm{C}_{13} \mathrm{H}_{12} \mathrm{O}_{4}$ & 232.24 \\
4 & 14.15 & Quercetin & $\mathrm{C}_{15} \mathrm{H}_{10} \mathrm{~N}_{7}$ & 302.24 \\
5 & 14.31 & Beta-Asarone & $\mathrm{C}_{12} \mathrm{H}_{16} \mathrm{O}_{3}$ & 208.26 \\
6 & 14.81 & Brachyamide B & $\mathrm{C}_{20} \mathrm{H}_{25} \mathrm{NO}_{3}$ & 327.42 \\
7 & 15.08 & Amurensin & $\mathrm{C}_{26} \mathrm{H}_{30} \mathrm{O}_{12}$ & 534.51 \\
8 & 15.53 & Piperitol & $\mathrm{C}_{20} \mathrm{H}_{20} \mathrm{O}_{6}$ & 356.37 \\
9 & 15.65 & Guineensine & $\mathrm{C}_{24} \mathrm{H}_{33} \mathrm{NO}_{3}$ & 383.53 \\
10 & 15.95 & Guineensine & $\mathrm{C}_{24} \mathrm{H}_{33} \mathrm{NO}_{3}$ & 383.53 \\
11 & 16.59 & Hesperidin & $\mathrm{C}_{28} \mathrm{H}_{34} \mathrm{O}_{15}$ & 610.56 \\
12 & 16.96 & $\mathrm{C}_{28} \mathrm{H}_{34} \mathrm{O}_{14}$ & 594.56 \\
13 & 17.68 & Didymin & $\mathrm{C}_{27} \mathrm{H}_{30} \mathrm{O}_{16}$ & 610.52 \\
14 & 17.79 & Rutin & $\mathrm{C}_{17} \mathrm{H}_{15} \mathrm{O}_{7}$ & 331.30 \\
15 & 17.96 & $\mathrm{C}_{12} \mathrm{H}_{10} \mathrm{O}_{6}$ & 250.05 \\
\hline
\end{tabular}


Table 2: Bioactivity of phytocomponents identified in the methanolic extracts of Piper sarmentosum by LC-MS.

\begin{tabular}{ccccc}
\hline No & RT & Name of compound & Nature of compound & Activity \\
\hline 1 & 11.53 & Dydimin & Flavonoid & Neuroprotective $e^{38}$, antioxidant properties, anticancer agent \\
2 & 14.15 & Quercetin & Flavonoid & Anticancer, anti-inflammatory, antibacterial, antiviral, antihepatotoxic and shows \\
allergenic properties & \\
3 & 15.08 & Amurensin & Flavanoid & Antioxidants properties \\
4 & 16.59 & Hesperidin & Flavanoid & Anti-inflammatory, antioxidant, hypolipidaemic and anti-carcinogenic actions ${ }^{43}$ \\
5 & 17.96 & Difucol & Phenol & Antioxidant, anti-inflammatory, antimicrobial and antidiabetic ${ }^{48}$ \\
\hline
\end{tabular}

high amount of active naringenin which is approximately $87.6 \%$. This amount of Naringenin had been evidence to reduced superoxide anions generation by up to $75.7 \%$., which make it a potent natural source of antioxidant.

Quercetin (4) is the commonest flavonoid in higher plants, usually present in glycosidic form. It may inhibit many enzymes including protein kinase C, lipogenases and lens aldose reductase. Quercetin also inhibits smooth muscle contraction and proliferation of rat lymphocytes. It is anti-gonadotropic, anti-inflammatory, antibacterial, antiviral and antihepatotoxic and shows some mutagenic activity and allergenic properties. ${ }^{30}$ Previous study had shown the hepatoprotective effects of Piper sarmentosum which is possibly through the effect of this compound. ${ }^{31}$

Beta Asarone is use in killing pest and bacteria but its uses had be limited due to its known adverse effects on toxicity. However it had also been shown to protect against cerebral ischemia by increasing antioxidant activities related to lesion pathogesis. ${ }^{32,33}$ Brachyamide B (6) is a minor amide of piper species. Amurensin may have therapeutic potential on allergic inflammation, which had been shown to have effect by inducing COX-2. ${ }^{34,35}$ While quercetin are a well known flavonoids derived from plants which are most diffused and derived flavonoids. It had been shown to affect immunity and inflammation by interacting with cell functions. ${ }^{36}$ Quercetin also has antoxidant scavenging effects on free radicals which may reduce the damages on cells membrane and cell death. It had also been shown to help protect against heart disease and cancer. $^{36}$

Didymin is a dietary flavonoid glycoside known to have antioxidant properties. ${ }^{29}$ It had been shown to be an effective oral agent for refractory neuroblastoma $^{37}$ and a neuroprotective agent ${ }^{38}$ in animal models. Hesperidin is one of the flavanoids in many Rutaceae families' for example; Citrus spp and Poncirus trifoliate. It is known as a supplement which is available over the counter. ${ }^{39}$ Supplemental hesperidin works best in reducing oedema or excess swelling in the legs. ${ }^{40}$ Hesperidin and rutin are vast and ranging in its ability to inhibit liver enzymes due to their antithyroid effects. ${ }^{41,42}$ It has also been shown to possess anti-inflammatoty, antioxidant, hypolipaedemic and anti-carcinogenic activities. $^{43}$

Pipentol is a known flavouring agent which are commoly used in fragrance chemistry. Guineensine is an alkaloid commonly found in piper sp. Studies had found that it has the ability to inhibit endocannabinoid uptake. ${ }^{44,45}$ Endocannabinoids has a role in inflammatory and pain, where it had been shown to inhibit proinflammatory cytokines and possess analgesic effects. Malvidine is an O-methylated anthocyanin usually act as a primary plant pigment (red/purplish colour of fruits/plant). It had been shown to eliminate damages caused by free radicals, ${ }^{46}$ antihypertensive activity and anti-inflammatory effect (blocking NF-kB pathway). ${ }^{47}$ Difucol, a phlorotannin commonly found in algae was also found in this extract which function is unclear and still being studied. Marcelo et al. ${ }^{48}$ had showed that difucol a phenols to have antioxidant, anti-inflammatory, anti-microbial and anti-carcinogenig properties.

As a conclusion. it is evident that Piper sarmentosum contains various bioactive compounds maily flavanoids. (1)(12) Didymin, (4)
Quercetin, (7) Amurensin, (11) Hesperidin, and (15) Difucol are new natural compounds that have not been reported before and most had been proven to have beneficial effects.

\section{CONCLUSION}

Further study on opportunities of piper sarmentosum as supplements or treatment of common ailment or diseases are warranted based on the presents of compounds which can be positively exploited as shown in the study.

\section{ACKNOWLEDGEMENTS}

This work was supported by GRANT, UKM Research Fund FF-2017-156. We would like to thank the Centre for Research and Instrumentation (CRIM) UKM, Bangi for their technical assistance.

\section{CONFLICTS OF INTEREST}

None declared.

\section{REFERENCES}

1. Aslam MS, Ahmad MS, Ahmad MA, Akhlaq M. An updated review on phytochemical and pharmacological properties of Piper saementosum. Current Trends in Biotechnology and Pharmacy. 2017;11(4):345-56.

2. Burkill IH. A dictionary of the Economic Products of the Malay Peninsula, second ed. Ministry of Agriculture and Cooperatives, Kuala Lumpur. 1966;176784.

3. Zakaria ZA, Patahuddin H, Mohamad AS, Israf DA, Sulaiman MR. In vivo antinociceptive and anti-inflammatory activities of the aqueous extract of the leaves of Piper sarmentosum. Journal of Ethnopharmacology. 2010;128(1):42-8.

4. Rahman MR, Abdul Razak F, Mohd Bakri M. Evaluation of wound closure activity of Nigella sativa Melastoma malabathricum, Pluchea indica, and Piper sarmentosum extracts on scratched monolayer of human gingival fibroblasts. Evidence-based Complement Altern Med. 2014;2014:190342.

5. Nair MG, Burke BA. Antimicrobial Piper metabolite and related compounds. Journal of Agriculture and Food chemistry. 1990;38:1093-6.

6. Atiax E, Ahmad F, Sirat H, Arbain D. Antibacterial activity and cytotoxicity screening of Sumathran Kaduk (Piper sarmentosum Roxb). Iran J Pharmacol Ther. 2010;10:1-5.

7. Diastutia H, Delsy EVY. Isolation and identification of antioxidant compounds leaf betel seating (Piper sarmentosum Roxb. Ex Hunter). Jurnal Eksakta. 2012;11:86-90.

8. Masuda T, Inazumi A, Yamada Y, Padolina WG, Kikuzaki H, Nakatani N Antimicrobial phenylpropanoids from Piper sarmentosum. Phytochemistry. 1991;30:3227-8.

9. Fernandez L, Daruliza K, Sudhakaran S, Jegathambigai R. Antimicrobial activity of the crude extract of Piper sarmentosum against methicilinresistant Staphylococcus aureus (MRSA), Escherichia coli, Vibrio cholera and Streptococcus pneumoniae. Eur Rev Med Pharmacol Sci. 2012;16:105-11.

10. Perry LM. Medicinal plants of East and Southeast Asia. MIT Press, Cambridge, MA. 1981;314-5.

11. Teerapon Dhippayom, Chuenjid Kongkaew, Nathorn Chaiyakunapruk. Clinical effects of thai herbal compress: A systematic review and meta-analysis. Evidence-Based Complementary and Alternative Medicine. 2015;2015;14.

12. Chanweethesuk A, Teerawutgulrag A, Rakariyatham N. Screening of antioxidant activity and antioxidant compounds of some edible plants of Thailand. Food Chemistry. 2005;92:491-7.

13. Pongmarutai M. Studying antidiabetic action of Piper rostratum. M.Sc. Thesis, Mahidol University, Bangkok, Thailand. 1980

14. Ridtitid W, Rattanaprom W, Thaina P, Methi S. Neuromuscular blocking activity of methanolic extract of Piper sarmentosum leaves in the rat phrenic nervehemidiaphragm preparation. Journal of Ethnopharmacology. 1998;61 (2):135-42. 
15. Najib Nik A, Rahman N, Furuta T, Kojima S, Takane K, Ali Mohd M. Antimalarial activity of extracts of Malaysian medicinal plants. Journal of Ethnopharmacology. 1999;64:249-54.

16. Sawangjaroen N, Sawangjaroen K, Poonpanang P. Effects of Piper longum fruit, Piper sarmentosum root and Quercus infectoria nut gall on caecal amoebiasis in mice. J Ethnopharmacol. 2004;91:357-60.

17. Angela M, David L, Lena F, Paola M, Sonia P, Stefanie W, et al. Phytochemical composition of Potentilla anserina L. analyzed by an integrative GC-MS and LCMS metabolomics platform. Metabolomics. 2013;9(3):599-607.

18. Do-Hoon Lee, Kwang-II Park, Hyeon-Soo Park,Sang-Rim Kang, Arulkumar Nagappan, et al. Flavonoids isolated from Korea Citrus aurantium L. Induce G2/M phase arrest and apoptosis in human gastric cancer AGS cells. EvidenceBased Complementary and Alternative Medicine. 2012;11.

19. Ugusman A, Zakaria Z, Hui CK, Nordin NA, Mahdy ZA. Flavonoids of Piper sarmentosum and its cytoprotective effects against oxidative stress. EXCLI J. 2012;11:705-14.

20. Vimala S, Mohd. Ilham A, Abdul Rashih A., Rohana S. Natural antioxidants: Piper sarmentosum (Kadok) and Morinda elliptica (Mengkudu). Malaysian Journal of Nutrition. 2004;9(1):41-51

21. RukachaisirikulT, Siriwattanakit $P$, Sukcharoenphol K, Wongvein $C$, Ruttanaweang $\mathrm{P}$, et al. Chemical constituents and bioactivity of Piper sarmentosum. Journal of Ethnopharmacology. 2004;93:173-6.

22. Chan EWC, Wong SK Chan. Phytochemistry and pharmacology of three Piper species: An update. International Journal of Pharmacognosy. 2014;1(9):534-44.

23. Miean KH, Mohamed S. Flavonoid (Myricetin, Quercetin, Kaempferol, Luteolin, and Apigenin) content of edible tropical plants. Journal of Agricultural and Food Chemistry. 2001;49:3106-12.

24. Aunpak J, Sriubolmas N, De-Eknamkul W, Ruangrungsi N. Essential oils of Piper sarmentosum: Chemical composition and anti-microbial activity. Proc 23rd Congress on Science and Technology of Thailand, Chiang Mai, Thailand. 1997:264-5.

25. Pittaya T, Photchana P, Pootaeng-On Y, Taylor WC. Chemical constituents of the roots of Piper Sarmentosum. Chemical \& Pharmaceutical Bulletin. 2006;54(2):149-51.

26. Nissanka APK, Veranja K, Rutnayake BMB, Vijaya K, Tsutomu N, Masatoshi N, Akira I, Tillekeratne LMV, Wijesundara DSA, Leslie GAA. Antimicrobial Alkaloids from Zanthoxylum tetraspermum and caudatum: Phytochemistry. 2001;56:85761.

27. Hertog MGL, Hollman PCH, Katan MB. Content of potentially anticarcinogenic flavonoids of 28 vegetables and 9 fruits commonly consumed in the Netherlands. J Agric Food Chem. 1992;41:2379-83.

28. Stohr J R, Xiao P G, Bauer R. Isobutylamides and a new methylbutylamide from Piper sarmentosum. Planta Medica. 1999;65:175-7.

29. Hung JY, Hsu YL, Ko YC, Tsai YM, Yang CJ, Huang MS, Kuo PL. Didymin, a dietary flavonoid glycoside from citrus fruits, induces Fas-mediated apoptotic pathway in human non-small-cell lung cancer cells in vitro and in vivo. Lung Cancer. 2010;68:366-74.

30. Kim BH, Choi JS, Yi EH. Relative antioxidant activities of quercetin and its structurally related substances and their effects on NF- $\kappa$ B/CRE/AP-1 signaling in murine macrophages. Mol Cells. 2013;35(5):410-20.

31. Nur Azlina MF, Kamisah $Y$, Renny AR, Faizah O. Piper sarmentosum protects lungs against oxidative stress induced by $\mathrm{CCl}_{4}$ in rats. Jr. Medicinal Plant Research. 2011;5(26):6128-35
32. Zuba D, Byrska B. Alpha- and beta-asarone in herbal medicinal products. A case study. Forensic Science International. 2012;223:1-3.

33. Yang YX, Chen YT, Zhou X J, Hong CL, Li CY, Guo JY. Beta-asarone, a major component of Acorus tatarinowii Schott, attenuates focal cerebral ischemia induced by middle cerebral artery occlusion in rats. BMC Complementary and Alternative Medicine. 2013;13.

34. Yi-Tang Li, Chun-Suo Yao, Jin-Ye Bai, Gui-Fang Cheng. Anti-inflammatory effect of amurensin $\mathrm{H}$ on asthma-like reaction induced by allergen in sensitized mice. Acta Pharmacologica Sinica. 2006;27(6):735-40.

35. Ahmed SI, Hayat MQ, Tahir M. Pharmacologically active flavonoids from the anticancer, antioxidant and antimicrobial extracts of Cassia angustifolia Vahl. BMC Complement Altern Med. 2016;16(1):460.

36. Anand David A, Arulmoli R, Parasuraman S. Overviews of biological importance of quercetin: A bioactive flavonoid. Pharmacognosy Reviews. 2016;10(20):84.

37. Singhal SS, Singhal S, Singhal $P$, Singhal J. Didymin: An orally active citrus flavonoid for targeting neuroblastoma. Oncotarget. 2017;8(17):29428-41.

38. Morelli S, Piscioneri A, Salerno S, Al-Fageeh MB, Drioli E, De Bartolo L. Neuroprotective effect of didymin on hydrogen peroxide-induced injury in the neuronal membrane system. Cells Tissues Organs. 2014;199:184-200.

39. Kamel KM, Abd El-Raouf OM, Metwally SA, Abd El-Latif HA, El-sayed ME. Hesperidin and rutin, antioxidant citrus flavonoids, attenuate cisplatin-induced nephrotoxicity in rats. Journal of Biochemical and Molecular Toxicology. 2014;28(7):312-9.

40. Takashi Kometani, Takahisa Nishimura, Takashi Nakae, Hiroshi Takii, Shigetaka Okada. Synthesis of neohesperidin glycosides and naringin glycosides by cyclodextrin glucano-transferase from an Alkalophilic Bacillus Species. Bioscience, Biotechnology, and Biochemistry. 1996,60(4):645-9.

41. Arinç E, Yilmaz, D, Bozcaarmutlu A. Mechanism of inhibition of CYP1A1 and glutathione S-transferase activities in fish liver by quercetin, resveratrol, naringenin, hesperidin, and rutin. Nutrition and Cancer. 2015;67(1):137-44.

42. Panda S, Kar A. Antithyroid effects of naringin, hesperidin and rutin in $1-T<$ inf $>4</$ inf $>$ induced hyperthyroid rats: Possible mediation through 5'DI activity. Pharmacological Reports. 2014;66(6):1092-9.

43. Liu WY, Liou SS, Hong TY, Liu IM. Protective effects of hesperidin (Citrus Flavonone) on high glucose induced oxidative stress and apoptosis in a cellular model for diabetic retinopathy. Nutrients. 2017;9(12):1312.

44. Nicolussi S, Viveros-Paredes JM, Gachet MS, Rau M, Flores-Soto ME, Blunder $M$, Gertsch J. Guineensine is a novel inhibitor of endocannabinoid uptake showing cannabimimetic behavioral effects in BALB/c mice. Pharmacological Research. 2014;80:52-65.

45. Reynoso-Moreno I, Najar-Guerrero I, Escareno N, Flores-Soto M E, Gertsch J, Viveros-Paredes JM. An endocannabinoid uptake inhibitor from black pepper exerts pronounced anti-inflammatory effects in mice. Journal of Agricultural and Food Chemistry. 2017;65(43):9435-42.

46. Huang WY, Wang J, Liu YM, Zheng Q S, Li CY. Inhibitory effect of malvidin on TNF- $\alpha$-induced inflammatory response in endothelial cells. European Journal of Pharmacology. 2014;723(1):67-72.

47. Huang W, Zhu Y, Li C, Sui Z, Min W. Effect of blueberry anthocyanins malvidin and glycosides on the antioxidant properties in endothelial cells. Oxidative Medicine and Cellular Longevity. 2016;2016:1591803.

48. Marcelo D. Catarino, Artur M. S. Silva and Susana M. Cardoso. Fucaceae: A source of bioactive phlorotannins. International Journal of Molecular Sciences. 2017;18(6):1327. 
GRAPHICAL ABSTRACT

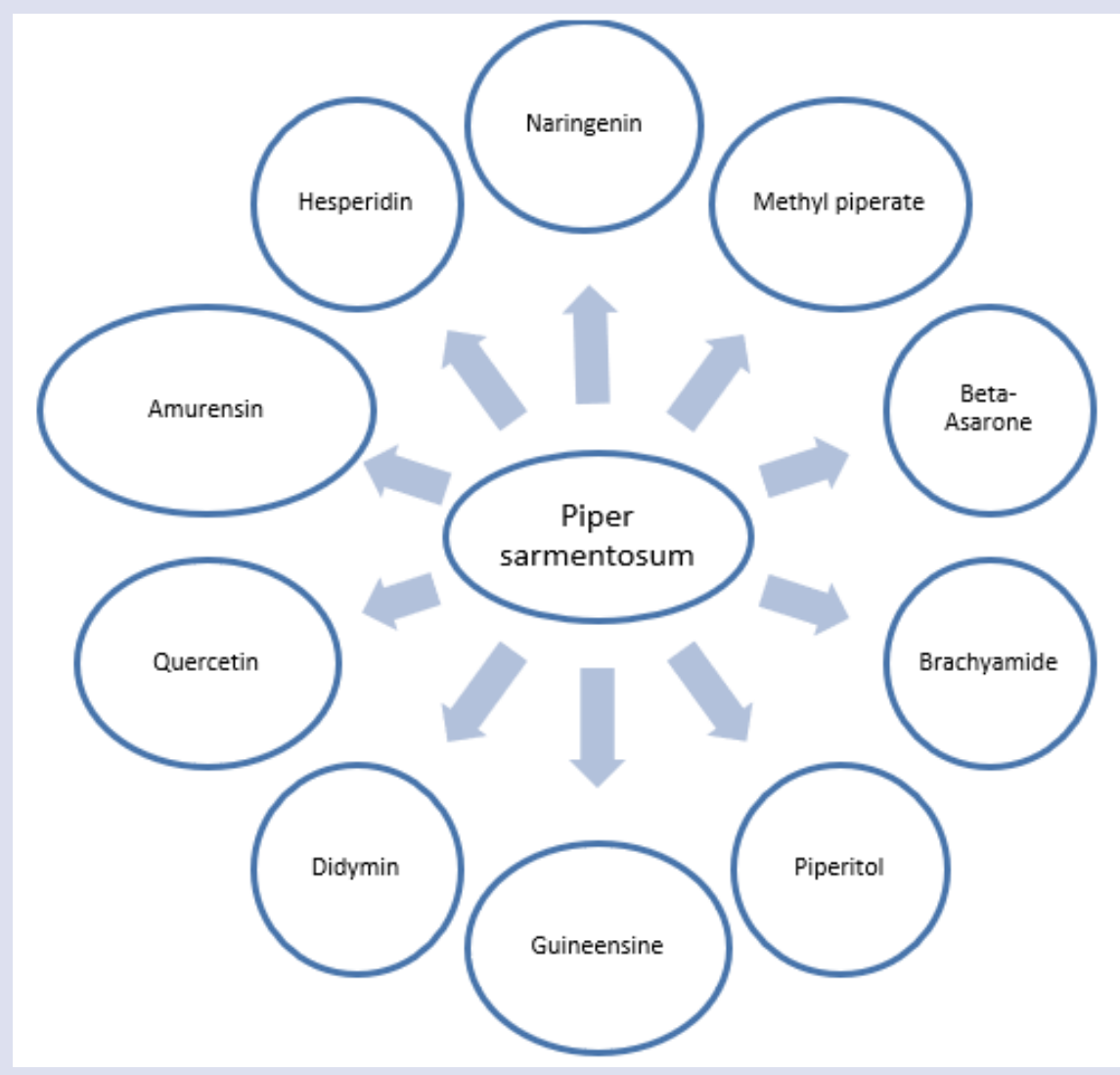

\section{ABOUT AUTHORS}

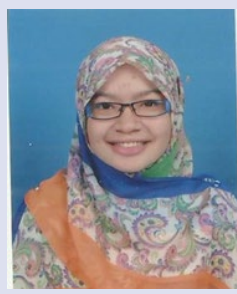

Cutt Fazzlieanie is currently working on her own business and trying to figure out suitable master program for her to pursue her imaginary dream. Cutt has been working at Microbiology department, Hospital Universiti Kebangsaan Malaysia (HUKM) as a research assistant and working on part of the research for Helicobacter pylori for a year. Previously, she has been doing her internship for several months also in HUKM, Cheras immediately after her degree program. Cutt loves to do writing and would love to have more scientific papers in future. Cutt's passion is more to pharmacology and also special needs education. Cutt graduated from Management and Science University with bachelors degree in Medical Science in 2017.

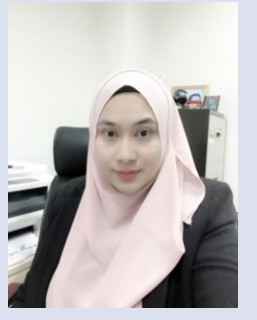

Associate Professor Dr Mohd Fahami Nur Azlina is the Head of the Stress Enzyme Research Group in Universiti Kebangsaan Malaysia. She graduated with a Doctor of Veterinary Medicine degree (UPM) and Doctor of Philosophy (UKM). She has been actively involved in research and teaching of Pharmacology. Over the last 17 years, she had focused her scientific interest on topics related to peptic ulcer diseases, metabolic syndrome and intervention with natural products. With expertise in animal model of gastric ulcers, interventional therapy with natural products and antioxidants, she had published more than 40 articles in world-renowned scientific journals.

Cite this article: Bactiar CF, Nur Azlina MF. LC-MS Analysis of Phytocomponents in the Methanol Extract of Piper Sarmentosum Leaves. Pharmacog J. 2019;11(5):1071-6. 